University of Nebraska - Lincoln

DigitalCommons@University of Nebraska - Lincoln

Faculty Papers and Publications in Animal

Science

Animal Science Department

January 1998

\title{
Effects of Inbreeding and Heterozygosity on Preweaning Traits in a Closed Population of Herefords Under Selection
}

\author{
L. Dale Van Vleck \\ University of Nebraska-Lincoln, dvan-vleck1@unl.edu
}

M. D. MacNeil

Livestock and Range Research Lab, USDA, ARS, Miles City, MT

Follow this and additional works at: https://digitalcommons.unl.edu/animalscifacpub

Part of the Animal Sciences Commons

Van Vleck, L. Dale and MacNeil, M. D., "Effects of Inbreeding and Heterozygosity on Preweaning Traits in a Closed Population of Herefords Under Selection" (1998). Faculty Papers and Publications in Animal Science. 273.

https://digitalcommons.unl.edu/animalscifacpub/273

This Article is brought to you for free and open access by the Animal Science Department at DigitalCommons@University of Nebraska - Lincoln. It has been accepted for inclusion in Faculty Papers and Publications in Animal Science by an authorized administrator of DigitalCommons@University of Nebraska - Lincoln. 


\title{
Effects of Inbreeding and Heterozygosity on Preweaning Traits in a Closed Population of Herefords Under Selection ${ }^{1}$
}

\author{
F. Pariacote*,2, L. D. Van Vleck†, and M. D. MacNeilł
}

*UNEFM, Departamento de Producción Animal, Apartado 7482, Coro, 4101, Venezuela;

${ }^{\dagger}$ Roman L. Hruska U.S. Meat Animal Research Center, USDA, ARS, Lincoln, NE 68583-0908; and ‡Livestock and Range Research Lab, USDA, ARS, Miles City, MT 59301

\begin{abstract}
Records of five inbred lines at the Livestock and Range Research Laboratory were used to evaluate effects of inbreeding and heterozygosity on preweaning traits. Members of each line were descendants of a single founder Hereford bull. A total of 8,065 records of birth weight and 7,380 records of preweaning daily gain and weaning weight were analyzed by derivative-free REML using a model that included fixed effects of sex, combination of year and month of birth and parity of dam, with covariates for direct and maternal genetic fractions of inheritance from the genetic groups, inbreeding, and heterozygosity fractions. Heterozygosity fractions were computed for crosses between lines. The random model effects were direct and maternal genetic and uncorrelated maternal permanent environmental and temporary environmental. Direct inbreeding and heterozygosity
\end{abstract}

fractions averaged .098 and .343, and maternal inbreeding and heterozygosity fractions averaged .075 and .294. Regression coefficients of traits on direct and maternal inbreeding fractions were $-5.8 \pm 1.1$ and -4.7 \pm 1.3 for birth weight, $-.189 \pm .031$ and $-.252 \pm .039$ for preweaning daily gain, and $-44.5 \pm 6.6$ and $-56.1 \pm$ $8.4 \mathrm{~kg}$ for weaning weight. Estimates for direct heritability, maternal heritability, and direct-maternal genetic correlations were .37, .12, and -.01 for birth weight; .16, .25, and -.27 for daily gain; and .17, .26 , and -.21 for weaning weight. Results suggest that heterosis represents recovery of accumulated inbreeding depression. Results also indicate that selection can overcome inbreeding depression and antagonism exists between direct and maternal genetic effects for preweaning traits.

Key Words: Beef Cattle, Inbreeding, Heterosis

O1998 American Society of Animal Science. All rights reserved.

J. Anim. Sci. 1998. 76:1303-1310

\section{Introduction}

The usual plan in formation of inbred lines has been to make genetic relationships to a desired animal as large as possible. Unfortunately, increased homozygosity, the primary genetic consequence of formation of inbred lines, has been associated with a decline in performance (Burrow, 1993).

I nbred lines have also been formed to create specific crosses that can take advantage of nonadditive genetic effects, under the hypothesis that heterosis is recovery of accumulated inbreeding depression that has occurred with the formation of inbred lines (Gregory et al., 1994). The bioeconomic importance of heterosis and the systems to take advantage of heterosis from generation to generation have been discussed by many

\footnotetext{
${ }^{1}$ Published as paper no. 11867, J ournal Ser., Nebraska Agric. Res. Div., Univ. of Nebraska, Lincoln 68583-0908.

${ }^{2}$ To whom correspondence should be addressed.

Received April 24, 1997.

Accepted December 5, 1997.
}

authors (e.g., Cundiff et al., 1992; Gregory et al., 1992a,b; Núñez-Dominguez et al., 1992; Newman et al., 1993; Davis et al., 1994). Within an environment, heterosis in a given trait seems to be a function of the genetic differences among inbred lines or groups being crossed. The goal of this study was to estimate the effects of inbreeding and effects of heterozygosity of line crosses on preweaning traits in a closed population of Hereford cattle under selection.

\section{Materials and Methods}

By the late 1920s, corn breeders had achieved success in developing hybrid varieties that outproduced their inbred parents based on the pioneering work of Shull (1908). Formation of the inbred lines in the initial phase of this research was apparently motivated by this success. Devel opment of inbred lines of beef cattle received much emphasis in the research programs of several western states as reviewed by Brinks and Knapp (1975). Fourteen of these inbred 
lines were located at Fort Keogh Livestock and Range Research Laboratory (LARRL), Miles City, Montana. Throughout their development, these lines were selected for postweaning growth and structural soundness. Five of the highest performing lines at LARRL were subsequently used in line crossing experiments (Brinks et al., 1967, 1972; Urick et al., 1968, 1983) that comprised the second phase of this research. In the third and final phase of this research, selection was relaxed and the line cross progenies were mated at random ( $\mathrm{Nelsen}$ et al., 1984, 1986; Reynolds et al., 1991). The preceding reports and Urick et al. (1966), MacNeil et al. (1992), and Ferreira (1996) provide detail regarding climatic conditions and livestock husbandry at LARRL.

Five inbred lines, each founded by a single Hereford bull, were identified as Line 1, Line 4, Line 6, Line 9, and Line 10. Each inbred line was composed of all descendants of a given founder bull, whether descendants came from mating the founder bull or descendants of the founder bull with the base population or from matings within the line. Line 1 remained closed to outside breeding from 1934 to 1971, Line 4 from 1947 to 1975, Line 6 from 1949 to 1975, Line 9 from 1951 to 1970 , and Line 10 from 1950 to 1975 . The base population, common to all lines, was defined as foundation males and females that did not have performance information of their own as well as other individuals from matings within that group. Five males and 306 females did not have performance records of their own. A total of seven genetic groups was formed, with groups 1 to 5 being Lines $1,4,6,9$, 10 and groups 6 and 7 being immigrants and the base population, respectively. Any individual not related to the inbred lines or the base population was considered an immigrant. Individuals with a composite genotype were considered to be line crosses (Table 1).

The genetic fraction contributed by an inbred line to an individual $\left(I g_{i}\right)$ was derived from the corresponding genetic line fractions of its parents, except in situations when an individual from a known inbred line was mated to an individual of the base population (Table 1). For example, $I g_{i}=1 / 2\left(S g_{i}+D g_{i}\right)$, where $S g_{i}$ and $D g_{i}$ represent the fractional genetic contributions of line $\mathrm{i}$ to the sire and dam, respectively, with $\Sigma I \mathrm{~g}_{\mathrm{i}}=1$ and $i=1, \ldots, 7$. Total heterozygosity was estimated as $1-\Sigma\left(\mathrm{Sg}_{\mathrm{i}} \mathrm{Dg_{ \textrm {i } }}\right)$ for $\mathrm{i}=1, \ldots, 6$, with the base population excluded. Inbreeding coefficients were computed with the MTDFNRM program of the MTDFREML package (Boldman et al., 1995). Descriptions of traits and covariates for direct and maternal genetic contributions are given in Table 2. Summary statistics for life span of groups and average inbreeding by group are in Table 3.

Traits were birth weight, preweaning daily gain, and weaning weight adjusted to $205 \mathrm{~d}$ of age. Singleand two-trait analyses were conducted with the MTDFREML program (Boldman et al., 1995) assum-
Table 1. Criteria for assignment to groups and number of individuals by group

\begin{tabular}{lcr}
\hline \hline Mating & Group formed & $\mathrm{n}$ \\
\hline Base population $\times$ base population & Base population & 191 \\
Line 1 & Line 1 & 252 \\
$\times$ base population & Line 1 & 2,321 \\
$\times$ Line 1 & & \\
Line 4 & Line 4 & 114 \\
$\times$ base population & Line 4 & 398 \\
$\times$ Line 4 & Line 6 & 101 \\
Line 6 & Line 6 & 325 \\
$\times$ base population & & \\
$\times$ Line 6 & Line 9 & 136 \\
Line 9 & Line 9 & 231 \\
$\times$ base population & & \\
$\times$ Line 9 & Line 10 & 122 \\
Line 10 & Line 10 & 283 \\
$\times$ base population & & \\
$\times$ Line 10 & Immigrants & 43 \\
Immigrants & & \\
$\times$ base population & Line cross & 747 \\
Line & & \\
$\times$ different line & Line cross & 2,299 \\
\hline Line cross & & \\
$\times$ line cross & & \\
\hline
\end{tabular}

ing the model $\mathbf{y}=\mathbf{X B}+\mathbf{Z}_{1} \mathbf{u}_{1}+\mathbf{Z}_{2} \mathbf{u}_{2}+\mathbf{Z}_{3} \mathbf{u}_{3}+\mathbf{e}$; where $\mathbf{y}=$ the vector of observations, $\mathbf{B}=$ vector of unobservable fixed effects, $\mathbf{u}_{1}=$ vector of random additive direct (as animal) genetic effects, $\mathbf{u}_{2}=$ vector of random additive maternal (as dam) genetic effects, $\mathbf{u}_{3}=$ vector of random uncorrelated maternal permanent environmental effects, $\mathbf{X}=$ matrix that relates elements of $y$ to fixed effects, $\mathbf{Z}_{1}=$ matrix that relates elements of $y$ to direct genetic effects, $\mathbf{Z}_{2}=$ matrix that relates elements of $\mathbf{y}$ to maternal genetic effects, $\mathbf{Z}_{3}=$ matrix that relates elements of $y$ to random uncorrelated maternal effects, and $\mathbf{e}=$ vector of residual effects.

All numerator relationships and inbreeding were included in calculation of the inverse of the numerator relationship matrix. Covariance between direct and maternal genetic effects was included in the covariance matrix for the random effects ( $\mathbf{u}_{1}$ and $\mathbf{u}_{2}$ ).

The vector of fixed effects included sex (bull, heifer, steer), combination of year of birth (1934 to 1988) with month of birth (March to J une), parity of dam (1 through 10), and covariates for the linear effects of direct and maternal genetic fractions from genetic groups and direct and maternal inbreeding and heterozygosity fractions.

Average merit of lines was calculated as $\Sigma\left(\mathrm{l}_{\mathrm{i}} \mathrm{b}_{\mathrm{i}}\right) / \Sigma \mathrm{l}_{\mathrm{i}}$, where $I_{i}$ represents the mean genetic fraction of the population from line $i, b_{i}$ is the regression coefficient of trait on genetic fraction from line $i$, for $i=$ Line $1, \ldots$, Line 10. The average inbreeding depression (AID) was calculated as $b_{F} * F$, where $b_{F}$ represents the regression coefficient of trait on inbreeding fraction and $F$ is the average inbreeding fraction across lines. 
Table 2. Description of traits and covariates

\begin{tabular}{|c|c|c|c|c|c|c|}
\hline Variable & $\mathrm{n}$ & Mean & SD & $\mathrm{CV}$ & Minimum & Maximum \\
\hline \multicolumn{7}{|c|}{ a) Preweaning traits, $\mathrm{kg}$} \\
\hline Birth weight & 8,065 & 34.5 & 4.7 & 13.7 & 10.4 & 56.2 \\
\hline Daily gain & 7,380 & .8 & .1 & 17.7 & .2 & 1.2 \\
\hline Weaning weight & 7,380 & 192.0 & 29.9 & 15.6 & 67.6 & 287.6 \\
\hline \multicolumn{7}{|c|}{ b) Covariates, fractions } \\
\hline \multicolumn{7}{|c|}{ Direct genetic contributions } \\
\hline Line 1 & & .426 & .427 & 100.3 & .0 & 1.000 \\
\hline Line 4 & & .161 & .269 & 166.7 & .0 & 1.000 \\
\hline Line 6 & & .156 & .257 & 165.3 & .0 & 1.000 \\
\hline Line 9 & & .066 & .227 & 342.6 & .0 & 1.000 \\
\hline Line 10 & & .133 & .246 & 184.0 & .0 & 1.000 \\
\hline Immigrants & & .035 & .106 & 307.2 & .0 & 1.000 \\
\hline Base population & & .024 & .152 & 642.1 & .0 & 1.000 \\
\hline Inbreeding & & .098 & .080 & 81.8 & .0 & .458 \\
\hline Heterozygosity & & .343 & .401 & 117.2 & .0 & 1.000 \\
\hline \multicolumn{7}{|c|}{ Maternal genetic contributions } \\
\hline Line 1 & & .396 & .437 & 110.4 & .0 & 1.000 \\
\hline Line 4 & & .146 & .269 & 183.4 & .0 & 1.000 \\
\hline Line 6 & & .147 & .260 & 177.6 & .0 & 1.000 \\
\hline Line 9 & & .050 & .209 & 420.7 & .0 & 1.000 \\
\hline Line 10 & & .123 & .247 & 201.2 & .0 & 1.000 \\
\hline Immigrants & & .021 & .075 & 361.6 & .0 & 1.000 \\
\hline Base population & & .119 & .323 & 272.7 & .0 & 1.000 \\
\hline Inbreeding & & .075 & .076 & 101.1 & .0 & .458 \\
\hline Heterozygosity & & .294 & .400 & 136.3 & .0 & 1.000 \\
\hline
\end{tabular}

The effect of heterosis was calculated as $b_{H} * H-A I D$, where $b_{H}$ represents the regression coefficient of trait on heterozygosity fraction and $\mathrm{H}$ represents the average heterozygosity fraction.

To estimate trends for genetic merit and inbreeding effect, breeding values and inbreeding depression were estimated for each individual in the population, with inbreeding depression calculated as the product of inbreeding fraction and the across-line coefficient of regression on inbreeding fraction. Regressions of breeding value and inbreeding depression on year of birth for direct and maternal genetic contributions were calculated within each line for the time period the lines were closed (all lines included) and within the line cross group.

\section{Results and Discussion}

Line Effects. The analysis constrained the solution for the base population to be zero. Partial regression coefficients in Table 4 associated with genetic fractions of inbred lines indicate the phenotypic change in the trait when the proportion of genes from an inbred line changes from none to all. This change measures

Table 3. Life span of groups, and number of individuals and averages of direct and maternal inbreeding coefficients (fraction) by group and trait

\begin{tabular}{|c|c|c|c|c|c|c|c|}
\hline Group & Life $\operatorname{span}^{a}$ & $\mathrm{n}$ & \multicolumn{2}{|c|}{ Birth weight } & $\mathrm{n}$ & \multicolumn{2}{|c|}{ Weaning weight ${ }^{b}$} \\
\hline Line 1 & $1931-73$ & 2,553 & .143 & .104 & 2,432 & .142 & .104 \\
\hline Line 6 & 1949-75 & 427 & .135 & .076 & 406 & .135 & .075 \\
\hline Line 9 & $1951-70$ & 367 & .085 & .030 & 336 & .081 & .026 \\
\hline Line 10 & $1950-75$ & 406 & .118 & .075 & 379 & .117 & .073 \\
\hline Line cross & $1958-88$ & 3,564 & .061 & .064 & 3,126 & .058 & .062 \\
\hline Population & $1923-88$ & 8,065 & .080 & .075 & 7,380 & .097 & .074 \\
\hline
\end{tabular}

${ }^{\mathrm{a} E}$ arliest and latest year of birth for members within a group. Recording of performance started in 1934

bSame for preweaning daily gain. 
Table 4. Partial regression coefficients (b) and standard errors (SE) of preweaning traits on direct and maternal line fractions, inbreeding, and heterozygosity fractions

\begin{tabular}{lccc}
\hline \hline & \multicolumn{4}{c}{ Preweaning traits, kg } \\
\cline { 2 - 5 } Covariate & $\begin{array}{c}\text { Birth weight } \\
\mathrm{b}^{\mathrm{a}} \pm \mathrm{SE}\end{array}$ & $\begin{array}{c}\text { Daily gain } \\
\mathrm{b}^{\mathrm{a}} \pm \mathrm{SE}\end{array}$ & $\begin{array}{c}\text { Weaning weight } \\
\mathrm{b}^{\mathrm{a}} \pm \mathrm{SE}\end{array}$ \\
\hline a) Direct genetic & & & \\
contribution & & & \\
Base population & $.00 \pm .00^{\mathrm{f}}$ & $.000 \pm .000$ & $.00 \pm .00$ \\
Line 1 & $1.21 \pm .95$ & $.012 \pm .020$ & $4.12 \pm 4.41$ \\
Line 4 & $-.21 \pm 1.47^{\mathrm{a}}$ & $-.025 \pm .030^{\mathrm{a}}$ & $-4.56 \pm 6.71^{\mathrm{a}}$ \\
Line 6 & $-.64 \pm 1.45^{\mathrm{bc}}$ & $-.024 \pm .030^{\mathrm{b}}$ & $-5.57 \pm 6.70^{\mathrm{b}}$ \\
Line 9 & $-.55 \pm 1.45^{\mathrm{de}}$ & $.009 \pm .030$ & $1.80 \pm 6.65$ \\
Line 10 & $2.63 \pm 1.46^{\mathrm{bd}}$ & $-.014 \pm .030^{\mathrm{c}}$ & $-.40 \pm 6.63^{\mathrm{c}}$ \\
Immigrant & $2.73 \pm 1.30^{\mathrm{acef}}$ & $.041 \pm .028^{\mathrm{abc}}$ & $11.19 \pm .61^{\mathrm{abc}}$ \\
Average & $.49 \pm 1.00$ & $-.008 \pm .020$ & $-.92 \pm 4.69$ \\
Inbreeding & $-5.80 \pm 1.14$ & $-.189 \pm .031$ & $-44.52 \pm 6.59$ \\
Heterozygosity & $.03 \pm .32$ & $.004 \pm .008$ & $.80 \pm 1.77$ \\
b) Maternal genetic contribution & & \\
Base population & $.00 \pm .00^{\mathrm{b}}$ & $.000 \pm .000^{\mathrm{cd}}$ & $.00 \pm .00^{\mathrm{bc}}$ \\
Line 1 & $.02 \pm .70$ & $.065 \pm .022^{\mathrm{abc}}$ & $13.78 \pm 4.70^{\mathrm{ab}}$ \\
Line 4 & $.88 \pm .77$ & $-.002 \pm .024^{\mathrm{a}}$ & $.41 \pm 5.36$ \\
Line 6 & $-.65 \pm .81^{\mathrm{a}}$ & $.049 \pm .026$ & $9.28 \pm 5.71$ \\
Line 9 & $.19 \pm .78$ & $-.007 \pm .025^{\mathrm{b}}$ & $-1.21 \pm 5.48^{\mathrm{a}}$ \\
Line 10 & $1.86 \pm .77^{\mathrm{ab}}$ & $.029 \pm .025$ & $8.22 \pm 5.36$ \\
Immigrant & $1.15 \pm 1.21$ & $.044 \pm .037$ & $10.08 \pm 8.19$ \\
Average & $.46 \pm 1.00$ & $.027 \pm .010^{\mathrm{d}}$ & $6.10 \pm 2.69^{\mathrm{c}}$ \\
Inbreeding & $-4.67 \pm 1.31$ & $-.252 \pm .039$ & $-56.10 \pm 8.41$ \\
Heterozygosity & $.02 \pm .37$ & $-.011 \pm .011$ & $-2.26 \pm 2.30$ \\
\hline
\end{tabular}

aSolutions with a common letter within a) or within b) are significantly different $(P<.05)$.

${ }^{b}$ Average for Lines $1,4,6,9$, and 10. the average difference in phenotypic merit of a line from the base population.

The average of the regression coefficients on direct fractions of genes of Lines $1,4,6,9$, and 10 was not significantly different from zero $(P>.05)$ for all traits (Section a of Table 4). Only the regression coefficient of birth weight on the direct immigrant gene fraction was different from that of the base population $(\mathrm{P}<$ .05). F or the maternal genetic contribution (Section $b$ of Table 4), the averages of the regression coefficients of preweaning daily gain and weaning weight on fractions of genes of Lines 1, 4, 6, 9, and 10 were different from those of the base population $(P<.05)$. Line 1 dams produced calves with greater preweaning daily gains and heavier weaning weights than the base population, despite not producing the heaviest calves at birth. Other differences in maternal line effects were close to zero, except for birth weight on the fraction of genes of Line 10. Of the total difference between the average merit of lines and the base population (Table 5 ), the direct genetic contribution accounted for .7 of change in birth weight, whereas for weaning weight, more than .9 of the change was due to the maternal genetic contribution. The ratio of more than 1.0 for the average merit of inbred lines to average inbreeding depression (Table 5) indicates that selection can overcome inbreeding depression, at least for the range of inbreeding of the lines studied.

Means and coefficients of regression of breeding value and inbreeding depression on year of birth for direct and maternal genetic contributions are shown in Table 6. The trends for direct and maternal inbreeding depression and for direct and maternal

Table 5. Average merit of lines, absolute and relative effects of inbreeding and heterozygosity, and amount of inbreeding depression recovered by heterosis for all groups

\begin{tabular}{|c|c|c|c|c|c|c|}
\hline \multirow[b]{2}{*}{ Trait } & \multicolumn{3}{|c|}{ Average effect of } & \multicolumn{2}{|c|}{ As $\%$ of raw mean } & \multirow{2}{*}{$\begin{array}{l}\text { Heterosis/ } \\
\text { Inbreeding }\end{array}$} \\
\hline & Lines $^{a}$ & Inbreeding ${ }^{b}$ & Heterosis ${ }^{c}$ & Inbreeding & Heterosis & \\
\hline \multicolumn{7}{|c|}{ a) Direct genetic contribution } \\
\hline Birth weight & .74 & -.57 & .58 & -1.65 & 1.68 & -1.02 \\
\hline Daily gain & -.00 & -.02 & .02 & -2.40 & 2.58 & -1.07 \\
\hline Weaning weight & .31 & -4.33 & 4.60 & -2.25 & 2.39 & -1.06 \\
\hline \multicolumn{7}{|c|}{ b) Maternal genetic contribution } \\
\hline Birth weight & .32 & -.35 & .35 & -1.01 & 1.02 & -1.01 \\
\hline Daily gain & .04 & -.02 & .02 & -2.42 & 2.03 & -.83 \\
\hline Weaning weight & 9.18 & -4.14 & 3.51 & -2.16 & 1.83 & -.84 \\
\hline \multicolumn{7}{|l|}{ c) Total } \\
\hline Birth weight & 1.06 & -.92 & .93 & -2.66 & 2.70 & -1.02 \\
\hline Daily gain & .04 & -.04 & .04 & -4.83 & 4.61 & -.95 \\
\hline Weaning weight & 9.49 & -8.47 & 8.11 & -4.41 & 4.22 & -.95 \\
\hline
\end{tabular}

${ }^{a}$ Average merit for inbred lines $=\Sigma\left(\mathrm{l}_{\mathrm{i}} \mathrm{b}_{\mathrm{i}}\right) / \Sigma \mathrm{l}_{\mathrm{i}}$, where $\mathrm{l}_{\mathrm{i}}$ represents the mean genetic fraction from line, $\mathrm{i}, \mathrm{b}_{\mathrm{i}}$ is the regression coefficient of trait on line fraction, and $\mathrm{i}=$ Line $\mathrm{I}, \ldots$.., Line 10

${ }^{b}$ Average inbreeding depression $(A I D)=b_{F} * F$; where $b_{F}$ represents the regression coefficient of trait on inbreeding coefficient, and $\mathrm{F}$ represents the average inbreeding.

${ }^{C} \mathrm{H}$ eterosis $=\mathrm{b}_{\mathrm{H}} * \mathrm{H}-\mathrm{AID}$, where $\mathrm{b}_{\mathrm{H}}$ represents the regression coefficient of trait on heterozygosity fraction, and $\mathrm{H}$ represents average heterozygosity. 
Table 6. Means and regression coefficients with standard errors (SE) of direct and maternal breeding values $\left(b_{\mathrm{BV}}\right)$ and direct and maternal inbreeding depression $\left(\mathrm{b}_{\mathrm{ID}}\right)$ on calf year of

birth within group (lines or line cross) by trait

\begin{tabular}{|c|c|c|c|c|c|c|c|c|c|c|c|c|c|c|c|c|}
\hline \multirow[b]{3}{*}{ Groups } & \multicolumn{8}{|c|}{ Birth weight, kg } & \multicolumn{8}{|c|}{ Weaning weight, $\mathrm{kg}$} \\
\hline & \multicolumn{4}{|c|}{ Breeding value } & \multicolumn{4}{|c|}{ Inbreeding depression } & \multicolumn{4}{|c|}{ Breeding value } & \multicolumn{4}{|c|}{ Inbreeding depression } \\
\hline & \multicolumn{2}{|c|}{ Mean \pm SE } & \multicolumn{2}{|c|}{$\mathrm{b}_{\mathrm{BV}} \pm \mathrm{SE}$} & \multicolumn{2}{|c|}{ Mean \pm SE } & \multicolumn{2}{|c|}{$b_{I D} \pm S E$} & \multicolumn{2}{|c|}{ Mean \pm SE } & \multicolumn{2}{|c|}{$\mathrm{b}_{\mathrm{BV}} \pm \mathrm{SE}$} & \multicolumn{2}{|c|}{ Mean \pm SE } & \multicolumn{2}{|c|}{$b_{I D} \pm S E$} \\
\hline \multicolumn{17}{|c|}{ a) Direct genetic contribution } \\
\hline Line 1 & 1.25 & .03 & .11 & .00 & -.83 & .01 & -.03 & .00 & 5.09 & 11 & .39 & .01 & -6.35 & .06 & -.23 & .01 \\
\hline Line 4 & 1.90 & .08 & .16 & .01 & -.80 & .03 & -.06 & .00 & 4.05 & .25 & .54 & .02 & -6.14 & .20 & -.46 & .02 \\
\hline Line 6 & -.38 & .07 & .04 & .01 & -.78 & .03 & -.06 & .00 & .68 & 15 & .10 & .02 & -5.95 & .21 & -.45 & .02 \\
\hline Line 9 & -.09 & .07 & -.03 & .01 & -.49 & .02 & -.04 & .00 & -3.25 & 19 & .24 & .03 & -3.75 & .18 & -.33 & .03 \\
\hline Line 10 & .05 & .07 & -.03 & .01 & -.68 & .03 & -.06 & .00 & 2.15 & 17 & .02 & .02 & -5.21 & 21 & -.43 & .02 \\
\hline All lines & .94 & .03 & .05 & .00 & -.78 & .01 & -.03 & .00 & 3.53 & .09 & .17 & .01 & -5.95 & .06 & -.22 & .00 \\
\hline Line cross & 1.16 & .03 & .02 & .00 & -.35 & .00 & -.02 & .00 & 4.78 & .08 & .03 & .01 & -2.71 & .04 & -.11 & .00 \\
\hline \multicolumn{17}{|c|}{ b) Maternal genetic contribution } \\
\hline Line 1 & .91 & .01 & .04 & .00 & -.48 & .01 & -.03 & .00 & 4.43 & .15 & .56 & .02 & -5.81 & .09 & -.38 & .01 \\
\hline Line 4 & -.05 & .03 & -.01 & .00 & -.33 & .02 & -.04 & .00 & 5.44 & .26 & .41 & .03 & -4.01 & .23 & -.53 & .02 \\
\hline Line 6 & -.07 & .02 & .00 & .00 & -.35 & .02 & -.04 & .00 & 6.90 & .24 & .10 & .03 & -4.24 & .25 & -.52 & .02 \\
\hline Line 9 & .72 & .03 & .00 & .01 & -.14 & .01 & -.03 & .00 & 10.38 & .27 & .32 & .05 & -1.68 & .16 & -.32 & .03 \\
\hline Line 10 & -.08 & .02 & -.01 & .00 & -.34 & .02 & -.05 & .00 & 6.08 & .27 & .21 & .04 & -4.13 & .26 & -.55 & .02 \\
\hline All lines & .59 & .01 & .01 & .00 & -.41 & .01 & -.02 & .00 & 5.46 & .11 & .34 & .01 & -4.92 & .07 & -.25 & .01 \\
\hline Line cross & .02 & .01 & -.04 & .00 & -.30 & .00 & .00 & .00 & 4.66 & .12 & -.55 & .01 & -3.57 & .06 & -.01 & .01 \\
\hline
\end{tabular}

breeding values for individuals combined are shown in Figure 1.

For the period the lines were closed (1934 to 1975), maternal breeding value for weaning weight increased more than direct breeding value (Figure 1b). For birth weight the opposite happened: the increase over years in direct breeding value was larger than the increase in maternal breeding value (Figure 1a). The within-line regression coefficients for direct and maternal breeding values on year of birth (Table 6) show that the yearly increase in maternal genetic merit was twice the yearly increase in direct genetic merit for weaning weight (.34 vs $.17 \mathrm{~kg} / \mathrm{yr}$ ). For birth weight the yearly increase in direct genetic merit was five times larger than the yearly increase in maternal genetic merit (.05 vs $.01 \mathrm{~kg} / \mathrm{yr}$ ).

Formation of lines resulted in increased weaning weight due to improvement of the maternal genetic potential. Straight line dams had calves with greater preweaning daily gain and weaning weight than dams from the base population. Selection for maternal performance will improve weaning weight in addition to gain from selection for direct performance (e.g., Van Vleck et al., 1977). The unbalanced relationship observed between the direct and maternal genetic contributions indicates that part of the phenotypic gain expected for preweaning traits from selecting either for direct or for maternal additive genetic potential will be offset by loss in the other, and that the total selection response will be less than that expected from heritability of either of the two effects.

Within lines, the ratios of the yearly increase for birth and weaning weight in direct breeding values to the yearly direct inbreeding depression were 1.7 and
.8 and for maternal breeding values were .5 and 1.4 , respectively. These ratios indicate that selection response for direct genetic merit overcame the inbreeding depression only for birth weight, and that selection response to maternal genetic contribution overcame accumulated inbreeding depression only for weaning weight. This result agrees with the phenotypic merit of lines described previously shown in Table 5. Within the line cross group, a downward trend was evident in the direct and maternal genetic merit for weaning weight.

Differences Among Lines. The regressions of traits on fractions of genes from the lines were not homogenous across lines. Differences among lines can be due to differential selection response or fixation of genes coming from founders. Each founder bull came from a different population. Only the Line 1 founder came from the base population (e.g., U rick et al., 1966). The fact that Line 1 differed from the base population only for daily gain and weaning weight suggests that birth and weaning weight are influenced by some genes with effects not common to both traits. This result is consistent with previous reports (MacNeil et al., 1992).

Means and regression coefficients associated with inbreeding depression were similar for all lines, but means and regression coefficients for year of birth associated with direct and maternal breeding values varied among lines (Table 6). The rankings of lines for direct and maternal genetic merits changed for birth and weaning weight, as well as for yearly increases in breeding values. Lines 4 and 1 averaged the largest direct genetic merit, and Lines 1 and 9 averaged the largest maternal genetic merit for birth 
2.5

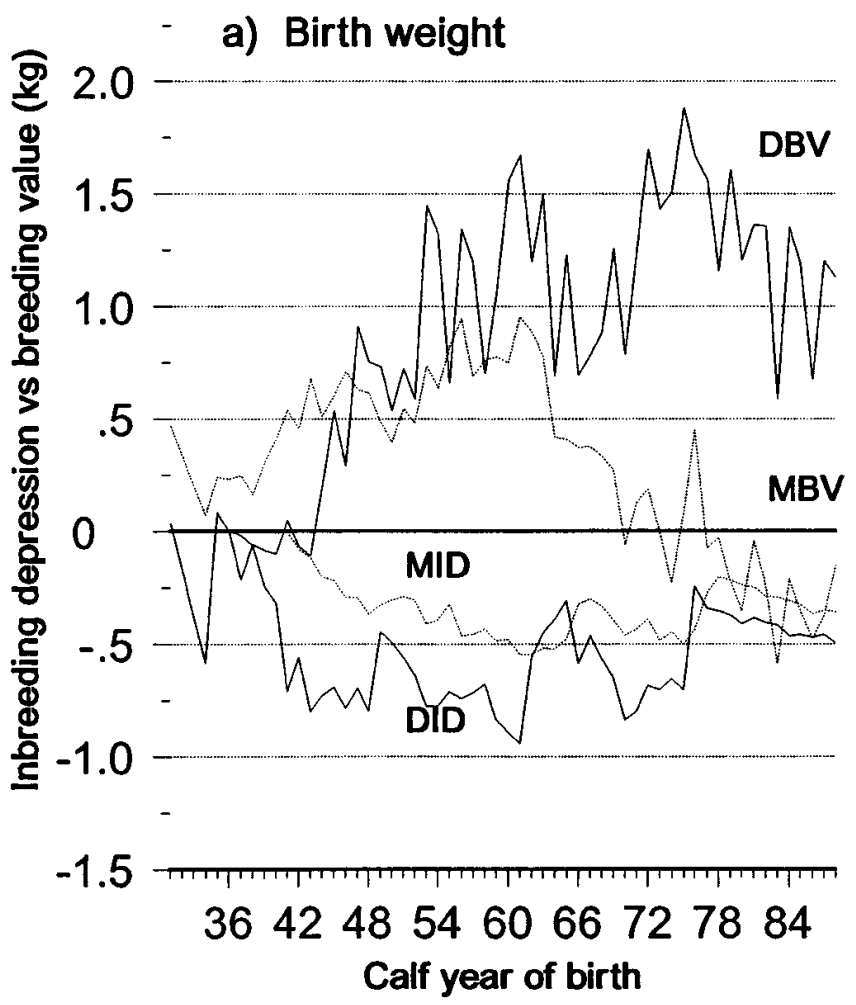

15

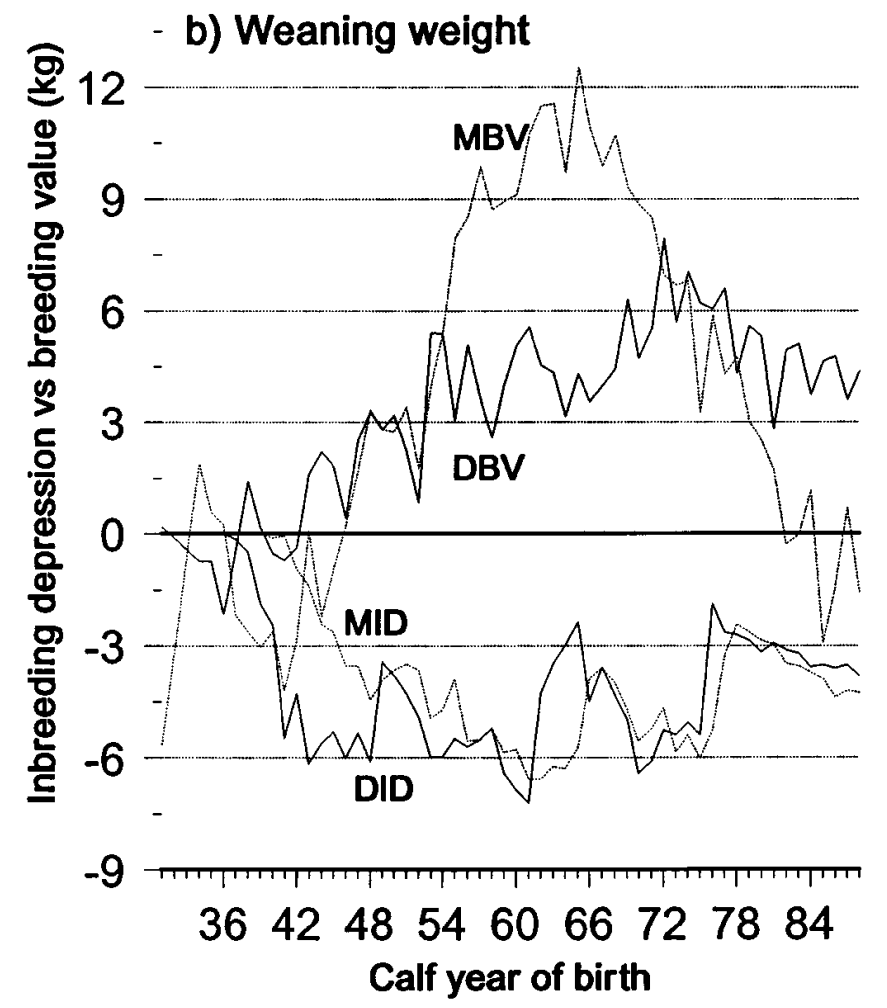

Figure 1. Trends for effects of direct (DID) and maternal (MID) inbreeding depression and direct (DBV) and maternal (MBV) breeding values for birth and weaning weight for all individuals combined.

and weaning weight, respectively. For birth weight, a yearly decrease in breeding value was observed for direct genetic merit in Lines 9 and 10 and for maternal genetic breeding value in Lines 4 and 10. However, for all lines combined, breeding values for direct and maternal genetic contributions to weaning weight increased over the years.

On the average, the increase in direct and maternal breeding values for birth weight was also expressed in weaning weight. Line 4 had the largest yearly increase in direct breeding value for birth and weaning weights. Similarly, Line 1 had the largest yearly increase in maternal breeding value for birth and weaning weights.

Differences between the largest and smallest means for direct breeding values were 2.3 and 8.3 and for maternal breeding values were 1 and $6 \mathrm{~kg}$ for birth and weaning weight, respectively. The differences among lines are consistent with previous reports (Brinks et al., 1965, 1967, 1972) and show that real additive genetic differences existed among the lines that might be associated with fixation of some founder genes.

Inbreeding Effects. The pooled across-line regression coefficients of performance on direct and maternal inbreeding fractions (Table 4) differed from zero for all traits $(P<.05)$. These partial regression coefficients are within the range reported by Burrow
(1993), except for the regression coefficient of birth weight on maternal inbreeding fraction. The observed significant and negative effect of maternal inbreeding on birth weight is contrary to some previous reports. Brinks et al. (1965) and MacNeil et al. (1988) reported regression coefficients of birth weight on maternal inbreeding that were slightly positive, although not significantly different from zero. However, Snelling et al. (1996) in an across-environment analysis reported the same pattern as in this study. The inconsistency of the effect of maternal inbreeding on birth weight might be associated with an interaction between levels of maternal inbreeding and direct inbreeding.

Table 5 shows the average depression across lines due to increase in direct and maternal inbreeding in the population. Of the total accumulated inbreeding depression, direct inbreeding accounted for about $62 \%$ of the depression for birth and $51 \%$ for weaning weight, which agree with previous reports (Burrow, 1993).

Heterozygosity. Much as expected, the regression coefficients associated with direct and maternal heterozygosity did not differ significantly from zero (Table $4 a, b)$. Under the hypothesis of dominance, which seems to be the case for growth traits in beef cattle (K ress et al., 1992; Gregory et al., 1994), heterozygosity has an effect opposite to that of inbreeding. Thus, 
Table 7. Fractions of phenotypic variances ${ }^{\mathrm{a}}$ associated with, and correlations among, random effects

\begin{tabular}{|c|c|c|c|c|c|c|c|c|c|c|c|c|c|}
\hline \multirow[b]{2}{*}{ Random effects } & & \multicolumn{4}{|c|}{ Birth weight } & \multicolumn{4}{|c|}{ Weaning weight } & \multicolumn{4}{|c|}{ Daily gain } \\
\hline & & $a_{1}$ & $\mathrm{~m}_{1}$ & $\mathrm{c}_{1}$ & $e_{1}$ & $a_{2}$ & $\mathrm{~m}_{2}$ & $c_{2}$ & $e_{2}$ & $a_{3}$ & $m_{3}$ & $c_{3}$ & $e_{3}$ \\
\hline \multicolumn{14}{|l|}{ a) Single trait analysis } \\
\hline Direct genetic & $\left(a_{i}\right)$ & .37 & -.01 & - & - & .17 & -.21 & - & - & .16 & -.27 & - & - \\
\hline Maternal genetic & $\left(m_{i}\right)$ & & .12 & - & - & & .26 & - & - & & .25 & - & - \\
\hline Maternal environmental & $\left(c_{i}\right)$ & & & .06 & - & & & .14 & - & & & 15 & - \\
\hline Residual & $\left(e_{i}\right)$ & & & & .45 & & & & .48 & & & & .14 \\
\hline \multicolumn{14}{|l|}{ b) Two-trait analysis } \\
\hline Direct genetic & $\left(a_{1}\right)$ & .36 & .03 & - & - & .50 & 10 & - & - & & & & \\
\hline Maternal genetic & $\left(m_{1}\right)$ & & .13 & - & - & .22 & .41 & - & - & & & & \\
\hline Maternal environmental & $\left(c_{1}\right)$ & & & .06 & - & & & .36 & - & & & & \\
\hline Residual & $\left(e_{1}\right)$ & & & & .45 & & & & .35 & & & & \\
\hline Direct genetic & $\left(a_{2}\right)$ & & & & & .15 & .00 & - & - & & & & \\
\hline Maternal genetic & $\left(m_{2}\right)$ & & & & & & .21 & - & - & & & & \\
\hline Maternal environmental & $\left(c_{2}\right)$ & & & & & & & .16 & - & & & & \\
\hline Residual & $\left(e_{2}\right)$ & & & & & & & & .48 & & & & \\
\hline
\end{tabular}

aphenotypic variances $(\mathrm{kg})^{2}$ were as follows: birth weight, 17.7 ; weaning weight, 530.4 ; and daily gain, 0.011 .

the theoretical expectation is for heterosis to recover effects of inbreeding depression. This expectation implies that inbreeding is required in order for heterosis to be expressed in line crosses. In this study, the expectation was that the regression coefficient of a trait on heterozygosity would be zero because it measures the effect of heterozygosity given zero inbreeding. A negative regression coefficient associated with heterozygosity would indicate incomplete recovery for inbreeding depression, and a positive value would indicate recovery above expectation.

Mean effects of direct and maternal heterosis for all groups (Table 5) were estimated as deviations of the corresponding average effect of heterozygosity from the absolute average of inbreeding depression. The results agree with previous reports (Flower et al., 1963; Brinks et al., 1967; Brinks et al., 1972; Urick et al., 1981; MacNeil et al., 1982; Urick et al., 1983). Crossing lines recovered nearly all of the effects of inbreeding depression with ratios of $1.01, .95$, and .95, for birth weight, daily gain, and weaning weight, respectively (Table $5 c$ ). Effects of direct heterosis were greater than maternal heterosis for all traits. These results support the hypothesis that inbreeding depression on preweaning growth traits in beef cattle is due to a loss in heterozygosity that occurs in formation of lines and that heterosis is basically recovery of that depression.

Heritability Estimates. Estimates of heritability, shown in Table 7, are within the range reported in the literature for these traits (e.g., MacNeil et al., 1992; Mohiuddin, 1993; Koots et al., 1994; Ferreira, 1996; Van Vleck et al., 1996). The improvement observed for direct and maternal performance agrees with the moderate negative correlation found between additive direct and maternal effects for weaning traits (Table 7). Estimates of genetic correlation between birth and weaning weight were .50 for the direct genetic effects,
.41 for the maternal genetic effects, and .16 on the average between maternal and direct genetic effects of the two traits (Table 7).

\section{Implications}

In the populations of Hereford cattle that were developed under selected mating and with moderate increases in inbreeding, selection seemed to overcome accumulated inbreeding depression for preweaning traits. Crosses between lines recovered nearly all the inbreeding depression but seemed to dilute the differentiated genetic progress achieved among the lines. Selection for maternal performance would improve weaning traits in addition to gain from selecting for direct performance. A successful selection program seems possible even in small closed populations with moderate inbreeding.

\section{Literature Cited}

Boldman, K. G., L. A. Kriese, L. D. Van Vleck, C. P. Van Tassell, and S. D. Kachman. 1995. A Manual for Use of MTDFREML. A Set of Programs To Obtain Estimates of Variances and Covariances (draft). USDA, ARS, Lincoln, NE.

Brinks, J. S., R. T. Clark, and N. M. Kieffer. 1965. Evaluation of response to selection and inbreeding in a closed line of Hereford cattle. USDA Tech. Bull. 1323.

Brinks, J. S., and B. W. Knapp. 1975. Effects of inbreeding on performance traits of beef cattle in the western region. Tech. Bull. 123. Colorado State Univ., Fort Collins.

Brinks, J. S., B. W. Knapp, J. J . Urick, and O. F. Pahnish. 1972. Heterosis in preweaning maternal traits among lines of Hereford cattle. J. Anim. Sci. 34:14-20.

Brinks, J. S., J. J . Urick, O. F. Pahnish, B. W. Knapp, and T. J. Riley. 1967. Heterosis in Preweaning and weaning traits among lines of Hereford cattle. J. Anim. Sci. 26:278-284.

Burrow, H. M. 1993. The effect of inbreeding in beef cattle. Anim. Breed. Abstr. 61:737-751. 
Cundiff, L. V., R. Núñez-Dominguez, G. E. Dickerson, K. E. Gregory, and R. M. Koch. 1992. Heterosis for lifetime production in Hereford, Angus, Shorthorn, and crossbred cows. J. Anim. Sci. 70:2397-2410.

Davis, K. C., M. W. Tess, D. D. Kress, D. E. Doornbos, and D. C. Anderson. 1994. Life cycle evaluation of five biological types of beef cattle in a cow-calf range production system: II. Biological and economic performance. J. Anim. Sci. 72:2591-2598.

Ferreira, G. B. 1996. Genetic parameters for preweaning and growth traits estimated using different statistical models. Ph.D. thesis. University of Nebraska Graduate College, Lincoln.

Flower, A. E., J. S. Brinks, J. J . Urick, and F. S. Willson. 1963. Comparisons of inbred lines and linecrosses for performance traits in Hereford range cattle. J. Anim. Sci. 22:914-918.

Gregory, K. E., L. V. Cundiff, and R. M. Koch. 1992a. Breed effects and heterosis in advanced generations of composite populations for reproduction and maternal traits of beef cattle. J. Anim. Sci. 70:656-672.

Gregory, K. E., L. V. Cundiff, and R. M. Koch. 1992b. Effect of breed and retained heterosis on milk yield and 200-day weight in advanced generations of composite populations of beef cattle. J . Anim. Sci. 70:2366-2372.

Gregory K. E., L. V. Cundiff, and R. M. Koch. 1994. Germplasm utilization in beef cattle. Proc. 5th World Congr. Genet. Appl. Livest. Prod. 17:261-268.

Koots, K. R., J. P. Gibson, C. Smith, and J. W. Wilton. 1994. Analyses of published genetic parameter estimates for beef production traits. 1. Heritability. Anim. Breed. Abstr. 62: 309-338.

Kress, D. D., D. E. Doornbos, D. C. Anderson, and D. Rossi. 1992. Performance of crosses among Hereford, Angus, and Simmental cattle with different levels of Simmental breeding: VI. Maternal heterosis of 3- to 8-year-old dams and the dominance model. J. Anim. Sci. 70:2682-2687.

MacNeil, M. D., D. D. Dearborn, L. V. Cundiff, C. A. Dinkel, and K. E. Gregory. 1989. Effects of inbreeding and heterosis in Hereford females on fertility, calf survival and preweaning growth J. Anim. Sci. 67:895-901.

MacNeil, M. D., C. A. Dinkel, and L. D. Van Vleck. 1982. Individual and maternal additive and heterotic effects on 205-day weight in beef cattle. J. Anim. Sci. 54:951-956.

MacNeil, M. D., J . J . Urick, S. Newman, and B. W. Knapp. 1992. Selection for postweaning growth in inbred Hereford cattle: the Fort Keogh, Montana Line 1 example. J . Anim. Sci. 70:723-733.

Mohiuddin, G. 1993. Estimates of genetic and phenotypic parameters of some performance traits in beef cattle. Anim. Breed. Abstr. 61:495-522.
Nelsen, T. C., R. E. Short, J . J . Urick, and W. L. Reynolds. 1984. Genetic variance components of birth weight in a herd of unselected cattle. J. Anim. Sci. 59:1459-1466.

Nelsen, T. C., R. E. Short, J . J . Urick, and W. L. Reynolds. 1986. Heritabilities and genetic correlations of growth and reproductive measurements in Hereford bulls. J . Anim. Sci. 63:409-417.

Newman, S., M. D. MacNeil, W. L. Reynolds, B. W. Knapp, and J . J . Urick. 1993. Fixed effects in the formation of a composite line of beef cattle: II. Pre and postweaning growth and carcass composition. J. Anim. Sci. 71:2033-2039.

Núñez-Dominguez, R., G. E. Dickerson, L. V. Cundiff, K. E. Gregory, and R. M. Koch. 1992. Economic evaluation of heterosis and culling policies for lifetime productivity in Hereford, Angus, Shorthorn, and crossbred cows. J. Anim. Sci. 70:2328-2337.

Reynolds, W. L., J . J . Urick, D. A. Veseth, D. D. Kress, T. C. Nelsen, and R. E. Short. 1991. Genetic parameters by son-sire covariances for growth and carcass traits of Hereford bulls in a nonselected herd. J. Anim. Sci. 69:1000-1007.

Shull, G. H. 1908. The composition of a field of maize. Am. Breed. Assoc. 4:296-301.

Snelling, W. M., M. D. MacNeil, D. D. Kress, D. C. Anderson, and M. W. Tess. 1996. Factors influencing genetic evaluations of linebred Hereford cattle in diverse environments. J . Anim. Sci. 74:1499-1510.

Urick, J.J., J. S. Brinks, R. T. Clark, O. F. Pahnish, and F. S. Willson. 1966. History and performance of inbred lines of Hereford cattle developed at the U.S. Range Livestock Experiment Station. Montana Agric. Exp. Stn. Bull. 60. 22 pp.

Urick, J . J ., J . S. Brinks, O. F. Pahnish, B. W. Knapp, and T. M. Riley. 1968. Heterosis in postweaning traits among lines of Hereford cattle. J. Anim. Sci. 27:323-330.

Urick, J . J ., O. F. Pahnish, G. V. Richardson, and R. L. Blackwell. 1981. Comparison of two- and three-way rotational crossing and synthetic variety production involving inbred lines of Hereford cattle: Preweaning and weaning traits. J. Anim. Sci. 52:475-482.

Urick, J . J ., O. F. Pahnish, G. V. Richardson, and R. L. Blackwell. 1983. Comparison of two- and three-way rotational crossing and synthetic variety production involving inbred lines of Hereford cattle: postweaning traits. J . Anim. Sci. 57:577-584.

Van Vleck, L. D., D. St. Louis, and J. I. Miller. 1977. Expected phenotypic response in weaning weight of beef calves from selection for direct and maternal genetic effects. J. Anim. Sci. 44:360-367.

Van Vleck, L. D., K. E. Gregory, and G. L. Bennett. 1996. Direct and maternal genetic covariance by age of dam for weaning weight. J. Anim. Sci. 74:1801-1805. 